\title{
STRUCTURAL COMPLEXITY OF ARTIFICIAL HABITAT AND THE FEEDING SUCCESS OF PREDATORY DRAGONFLY AND DAMSELFLY
}

\author{
Khairuddin $\left({ }^{1}\right)$, Lalu Japa $\left({ }^{1}\right)$, dan Nur Lestari $\left({ }^{1}\right)$ \\ $\left(^{1}\right)$ Lecturers of Biology Education Program, PMIPA FKIP University of Mataram
}

\begin{abstract}
The effect of different habitat complexity structure on the feeding success of predatory Dragonfly and Damselfly over the four of three hours trials was tested using an artificial habitat complexity structure. Complexity of artificial habitat structure was performed using woody bamboo stick of $5 \mathrm{~cm}$ in length and $2 \mathrm{~mm}$ in diameter. The artificial habitats were set in plastic tank with length and wide of $17 \mathrm{~cm}$ and $11.5 \mathrm{~cm}$, respectively and $5.5 \mathrm{~cm}$ high. The deep of water colom was about $4.5 \mathrm{~cm}$. Preys were larvae of mosquitoes. There was highly significant of feeding success of predators in simple structure of habitats and significant enough in complex structure of habitats. In other words, feeding success of predatory Dragonfly and Damselfly was much higher in the simple habitats structure compared to that of the complex one.
\end{abstract}

Key Words : Artificial Habitat, Damselfly, Dragonfly, Feeding, and Predatory

\begin{abstract}
Abstrak
Pengaruh kompleksitas struktur habitat terhadap keberhasilan pemangsaan predator Dragonfly dan Damselfly selama empat kali tiga jam perlakuan diteliti di laboratorium menggunakan habitat buatan. Kompleksitas struktur habitat dibuat dengan tongkat dari bambu berukuran panjang $5 \mathrm{~cm}$ dengan diameter $2 \mathrm{~mm}$. Habitat buatan dibuat di bak plastik berukuran panjang dan lebar masing-masing $17 \mathrm{~cm}$ dan $11,5 \mathrm{~cm}$, dan tinggi $5,5 \mathrm{~cm}$ dengan kedalaman kolom air sekitar 4,5 cm. Larva nyamuk digunakan sebagai pangsa dalam penelitian ini. Setiap perlakuan terdiri dari dua ulangan. Setiap perlakuan berlangsung empat kali masing-masing selama tiga jam. Hasil memperlihatkan, keberhasilan pemangsaan Dragonfly dan Damselfly sangat signifikan pada habitat stuktur sederhana, dan cukup signifikan pada habitat yang kompleks. Dengan kata lain, keberhasilan pemangsaan Dragonfly dan Damselfly jauh lebih tinggi pada habitat berstruktur sederhana dibanding dengan pada habitat berstruktur kompleks.
\end{abstract}

Kata Kunci : Damselfly, Draggonfly, Habitat Buatan, Pemangsaan, Pemangsa (Predator) 


\section{INTRODUCTION}

In many freshwater systems, Odonata order (such as Dragonfly and Damselfly) could play such dominant roles in the continuity of the food webs. Odonata larvae are important predators in many freshwater habitats (Johnson, 1991). The Odonata order composed of two suborders: damselflies (Zygoptera), very slender insects, and dragonflies (Anisoptera), stronger-flying insects, and both larvae and adults stages of these insects are predators (Watson et al., 1991), lurkers carnivorous (Macan, 1973), carnivorous (Allbrook, 1979), or ambush predators (Swisher et al., 1998). The habitats of these two suborders of the Odonata refer primarily to the larval habitat (Watson et al., 1991).

Physical structure complexity of habitats has been believed to play several important ways in reduction of predation efficiency of predators. The structural complexity of habitat may provide, for example, a complete safe refuges for the prey (Crowder and Cooper, 1982). Ecological theory suggests that the impact of predation can be strongly modified by the existence of regions of environment in which prey are less accessible to predators (Hart and Merz, 1998). Habitat complexity and size reduction may be caused by reclamation of nature, or by man and intensification of human settlement (Klok and De Roos, 1998), or human activities result habitat pragmentation (Bender et al., 1998). Structurally complex habitats may reduce predation rates by providing absolute prey refuges where predators cannot physically reach prey individuals or by decreasing encounter rates between predators and their prey (Christensen and Persson, 1993). At low levels of structural complexity, predators are efficient, deplete the high profitability prey, and the system tends to become unstable (Crowder and Cooper, 1982). Habitat complexity can modify predation rates of both vertebrate and invertebrate predators
(William et al., 1993). The higher complexity of habitat structure, the greater species richness (Downs et al., 1998). The total average density of benthic invertebrates was significantly greater in the undisturbed areas (Kupriyanova and Bailey, 1998). The impact of fish predation on the prey community may be highly influenced by habitat structural complexity (Crowder and Cooper, 1982).

The primary objective of experiment is to study to what extent the complexity of habitat structure influences the intensity of succeed of sit and wait of predators in predation activity. The null hypothesis for this experiment is there are no differences in the feeding success of predatory dragonfly and damselfly in different complexity of artificial habitat structures (Ho $: \mu$ simple $=$ $\mu$ complex, or $\mu 1=\mu 2$ ). The alternative hypothesis is there are differences in the feeding success of predatory dragonfly and damselfly in different complexity of artificial habitat structures (HA : $\mu$ simple $\neq \mu$ complex, or $\mu 1 \neq \mu 2$ ). This work alters our understanding of the important of maintenance of habitat complexity and its implications for the management of wide range of natural ecosystems.

\section{MATERIALS AND METHODS}

The materials used in this research are woody bamboo stick (skewers) with about $2 \mathrm{~mm}$ diameter and $5 \mathrm{~cm}$ long, and plastic tank with the size of $17 \mathrm{~cm}$ long, $11.5 \mathrm{~cm}$ wide, and 5.5 $\mathrm{cm}$ high. The depth of water was approximately $4.5 \mathrm{~cm}$. Artificial complexity of habitat structures were modified by using woody bamboo stick (skewers). Larvae of mosquitoes were used as prey. The experiment was designed with a three factorial with two replications for each of set of treatments.

Two predators used in this research were larvae of the Dragonfly and Damselfly. The species of Dragonflies and Damselflies 
used in this present study are Aeshna brevistyla and Austroagrion cyane, respectively. Classification of both Dragonfly and Damselfly can be seen in Table 1 bellow. Larvae of mosquitoes were used as prey. Both these predators as well as prey are commonly found together in freshwater lakes, dams and ponds.

Table 1. Classification of Dragonfly and Damselfly

\begin{tabular}{c|l|l|l}
\hline No. & Nama of Taxa & Dragonfly & Damselfly \\
\hline 1. & Order & Odonata & Odonata \\
2. & Suborder & Anisoptera & Zygoptera \\
3. & Family & Aeshnidae & Coenagriondae \\
4. & Genus & Aeshna & Austroagrion \\
5. & Species & Aeshna brevistyla & Austroagrion cyane \\
\hline
\end{tabular}

Experiments were designed to find out the effects of habitat complexity in predation success of predatory Dragonfly and Damselfly. The experiments were run twice a week (or every 3 days), during a two months period. Because of the various size $(<0.5-$ $3.0 \mathrm{~cm}$ long) of both Dragonfly and Damselfly predators, so the number of predators in each set of experiment was not the same. This was the only one way to make the same biomass of predators in each set of experiments. Alterations before experiments were done to make the same conditions and the number of predators in each set of

\section{RESULTS AND DISCUSSION}

Statistical analysis representing that both simple (ANOVA: $\mathrm{F}=8.948$, df 2 , and $\mathrm{P}=$ $0.00054)$ and complex habitat structure types (ANOVA: $\mathrm{F}=3.141$, $\mathrm{df}=2$, and $\mathrm{P}=$ $0.05284)$ significantly affected the feeding success of predatory Dragonfly and Damselfly to the larvae of mosquito. However, it was not significant interaction between those habitat complexity (ANOVA: $\mathrm{F}=1.426$, $\mathrm{df}=4$, and $\mathrm{P}=0.24091$ ).

The results of this present study show that structural complexity of artificial habitat markedly increases the predation rates of the larvae of Dragonfly and Damselfly, independently or in combination of them. The predation ability of the larvae of experiment, because before trial some predators were death, or have been eaten during the trials. Ten mosquito larvae were sorted in each tank or set of experiments. The number of prey (mosquito larvae) eaten were counted after the trial has been run for a period of three hours, after which prey or mosquito larvae were putted to the tank. Whenever dead or metamorphosed predators were seen, they were removed from the trials and recorded.

The data were analyzed using TwoWay Factorial analysis of variance (ANOVA) (Zar, 1996).

Dragonfly is much higher than the larvae of Damselfly. Another desirable feature of Dragonfly is that it can kill large numbers of prey which could suggest an ability to reduce pest density rapidly. However, the predatory ability of combination of both Dragonfly and Damselfly larvae was not affected by the complexity structure of modified habitats. In term of average and the total number of mosquito larvae eaten was much greater in more complex habitat structure than the simple one. However, the feeding success of predatory Dragonfly was higher in all habitat types compared to the feeding success of Damselfly and when Dragonfly and Damselfly putted together in the same set of experiments. During the trial, some 
Damselfly and small dragonfly are eaten by the bigger Dragonfly.

Structural complexity of the habitat has been considered to play such prominent roles in determining of macro-invertebrate diversity. The average and total number of mosquito larvae eaten by Dragonfly, Damselfly and the combination of Dragonfly and Damselfly predators was much greater in complex habitat structure than in simple one. This is similarly to what has been reported by Menge (1978), that the rates of mussel predation are much greater in established seaweed stands. However, the total number of mosquito's larvae eaten by Dragonfly were higher than those eaten by Damselfly and the combination of Dragonfly and Damselfly. The later could be because the predation behavior of dragonfly does not appear to be selective to the real prey only, but its prey may also include the other smaller species of Odonata (Watson et al., 1991), such as Damselflies. On the other hand, all the Dragonfly nymphs are lurkers (Macan, 1973), therefore, the sit and wait successes of predators in complex structure of habitats may be primary due to prey are mobile (Forrester, 1994).

The lower feeding rates of the combination of Dragonfly andDdamselfly could be basically caused by firstly, the Dragonfly did not just eat the prey but the small Damselfly and Dragonfly as well. Therefore, they could get full before catch any mosquito larvae or the real prey. Beside that, the Damselfly and small Dragonfly predators could not feed normally because of scaring from predation of bigger Dragonfly. On the other hand, competition between them could affect their rates of feeding. The more feeding success of the Dragonfly compared to Damselfly may be because damselfly has lesser competitive ability than Dragonfly. The feeding rates are highly affected by competition between predators. Feeding rate was negatively related to competitor density (Triplet et al., 1999). Habitat complexity did not affect overall snail survival, but resulted in reduced predation pressure on the smaller size classes of snails (Nystrom and Perez, 1998).

Structural complexity of habitats could be used as a safe refuge areas for the prey (Kohn and Leviten, 1976; Crowder and Cooper, 1982), but because Dragonfly and Damselfly tend to wait and sit and hidden on that type of habitats, so more prey captured by them in more complex structure than in simple one. As they are waiting and hiding, the more the prey getting closer to them, the more they capture. This phenomenon could make the results of this study failed to support the results of some previous studies. For example, in the combination of fish and dragonfly predators ate on average 2.2 more larvae of Cloeon at low stem density (Swisher et al., 1998). Population density and species richness of predatory gastropods mollusks other than Conus increased significantly in the artificial increased habitat complexity (Kohn and Leviten, 1976). The densities of juvenile Pomacentrus moluccensis were higher in the more complex coral species. On the low complexity reefs with predators $P$. moluccensis recruits showed significantly lower final abundance than on all the other reefs (Beukers and Jones, 1997). Similarly, Collier et al. (1998) have found that the densities of invertebrates on macrophytes were significant higher compared to it densities on inorganic substrates only. Other study conducted by Vinson and Hawkins (1998) reported that stream insects appear to respond to both spatial and temporal variation in physical heterogeneity; and all the spatial data largely support the idea that physical complexity promotes biological richness. Survivorship of embryos of turtle at sited near vegetation was significantly higher than that of embryos away from vegetation (Wilson, 1998). Each element of habitat structure (large crevices, roughness, and macroalgae) promoted both increased species richness and densities of individuals (Downes et al., 1998). Furthermore, they 
have found that the higher species richness occurred on algal-covered, rough bricks than all other combinations of algal removal and roughness. Webster et al. (1998) have reported that the efficiency of predators on the infauna was highly reduced by the increasing of seagrass structural complexity. Much reduction of habitat complexity may reduce local invertebrate diversity (Schmude et al., 1998).

The feeding rates of Damselfly in all types of structural complexity of the artificial habitats are not so different and always lower than the feeding rates of Dragonfly. The steady rates of the feeding success of predatory Damselfly may support the result of study conducted by Koperski (1998), that the intensity of predation of larvae of the damselflies on leaf mining larvae of the chironomid decreased significantly in a habitat complexity. The average biomass of invertebrate predators was higher in intermediate density of vegetation compared to low and higher density of vegetation (Crowder and Cooper, 1982). In other words, they pointed out that low macrophyte density and high macrophyte density appear to be less profitable habitats. Predation are often more efficient in a low structure habitat (Crowder and Cooper, 1982).

\section{Conclusion}

Structural complexity of artificial habitat markedly increases the predation rates of the larvae of Dragonfly and Damselfly, independently or in combination of them. The feeding rates of Damselfly in all types of structural complexity of the artificial habitats were not so different and it was always lower than the feeding rates of Dragonfly. However, the predatory ability of combination of both Dragonfly and Damselfly larvae was not affected by the complexity structure of modified habitats. In term of average and the total number of mosquito larvae eaten was much greater in more complex habitat structure than the simple one. Structural complexity of the habitat has been considered to play such prominent roles in determining of macroinvertebrate diversity.

\section{References}

Allobrook, P., 1979, Tasmania Odonata, Fauna of Tasmania Committee, University of Tasmania, Hobart, Tasmania, Australia.

Bender, D.J., T.A. Contreras, and L. Fahrig, 1998, Habitat Loss and Population Decline: A Meta-Analyses of the Patch Size Effect, Ecology, 79(2): 517-533.

Beukers, J.S., and G.P. Jones, 1997, Habitat Complexity Modifies the Impact of Piscivores on a Coral Reef Fish Population, Oecologia, 114: 50-59.

Christensen, B., and L. Persson, 1993, Species-Specific Anti-Predator Behaviours: Effects on Prey Choice in Different Habitats, Behaviour Ecology Sociobiology, 32: 1-9.

Collier, K.J., R.J. Wilcock, and A.S. Meredith, 1998, Influence of Substrate Type and Physico-Chemical Conditions on Macroinvertebrate Faunas and Biotic Indices of Some Lowland Waikato, New Zealand, Streams, New Zealand Journal of Marine and Freshwater Research, 32: 1-19.

Crowder, L.B., and W.E. Cooper, 1982, Habitat Structural Complexity and the Interaction Between Bluegills and Their Prey, Ecology, 63(6): 1802-1813.

Downes, B.J., P.S. Lake, E.S.G. Schreiber, and A. Glaister, 1998, Habitat Structure and Regulation of Local Species Diversity in A Stony, Upland Stream, Ecological Monographs, 68(2): 237-257.

Forrester, G.E., 1994, Influences of Predatory Fish on the Drift Dispersal and 
Local Density of Stream Insects, Ecology, 75: 1208-1218.

Hart, D.D., and R.A. Merz, 1998, PredatorPrey Interactions in A Benthic Stream Community: A Field Test of FlowMediated Refuges, Oecologia, 114: 263273.

Johnson, D.M., 1991, Behavioral Ecology of Larval Dragonflies and Damselflies, Trends in Ecology and Evolution, 6: 813.

Klok, C., and A.M. De Roos, 1998, Effects of Habitat Size and Quality on Equilibrium Density and Extinction Time of Sorex araneus Populations, Journal of Animal Ecology, 67: 195-209.

Kohn, A.J., and P.J. Leviten, 1976, Effect of Habitat Complexity on Population Density and Species Richness in Tropical Intertidal Predatory Gastropod Assemblages, Oecologia (Berl.), 25: 199-210.

Koperski, P., 1998, Predator-Prey Interactions between Larval Damselflies and Mining Larvae of Glyptotendipes gripekoveni (Chironomidae)-Reduction in Feeding Activity as an Induced Defense, Freshwater Biology, 39(2): 317-324.

Kupriyanova, E.K., and C.F. Bailey, 1998, The Disturbance Effect of Largemouth Bass Nesting on a Benthic Macroinvertebrate Community, Journal of Freshwater Ecology, 13(3): 333-341.

Macan, T.T., 1973, Ponds and Lakes, George Allen \& Unwin Ltd., London.

Menge, B.A., 1978, Predation Intensity in a Rocky Intertidal Community. Effect of an Algal Canopy, Wave Actions and Desiccation on Predator Feeding Rates, Oecologia, 34: 17-35.

Nystrom, P., and J.R. Perez, 1998, Crayfish Predation on the Common Pond Snail (Lymnaea stagnalis)-The Effect Of
Habitat Complexity and Snail Size on Foraging Efficiency, Hydrobiologia, 368: 201-208.

Schmude, K.L., M.J. Jennings, K.J. Otis, and R.R. Piette, 1998, Effects of Habitat Complexity on Macroinvertebrate Colonization of Artificial Substrates in North temperate Lakes, Journal of the North American Benthological Society, 17(1): 73-80.

Swisher, B.J., D.A. Soluk, and D.H. Wahl, 1998, Non-Additive Predation in Littoral Habitats: Influences of Habitat Complexity, OIKOS: 81: 30-37.

Triplet, P., R.A. Stillman, and J.D. GrossCustard, 1999, Prey Abundance and the Strength of Interference in Foraging Shorebird, Journal of Animal Ecology, 68: $254-265$.

Vinson, M.R., and C.P. Hawkins, 1998, Biodiversity of Stream Insects-Variation at Local, Basin, and Regional Scales (Review), Annual Review of Entomology, 43: 271-293.

Webster, P.J., A.A. Eowden, and M.J. Attrill, 1998, Effect of Shoot Density on the Infaunal Macro-Invertebrate Community within a Zostera Marina Seagrass Bed, Estuarine Coastal \& Shelf Science, 47(3): 351-357.

Williams, D.D., J.A. Barnes, and P.C. Beach, 1993, The Effects of Prey Profitability and Habitat Complexity on the Foraging Success and Growth of Stonefly (Plecoptera) nymphs, Freshwater Biology, 29: 107-117.

Wilson, D.S., 1998, Nest-Site Selection: Microhabitat Variation and Its Effects on the Survival of Turtle Embryos, Ecology: 79(6): 1884-1892.

Zar, J.H., 1996, Biostatistical Analysis, Prentice-Hall International, Inc. 